\title{
Okullarda Göz Ardı Edilen Bir Konu: Cinsel Sağlık Eğitimi
}

\author{
Ignored Issue At Schools: Sexual Health Education
}

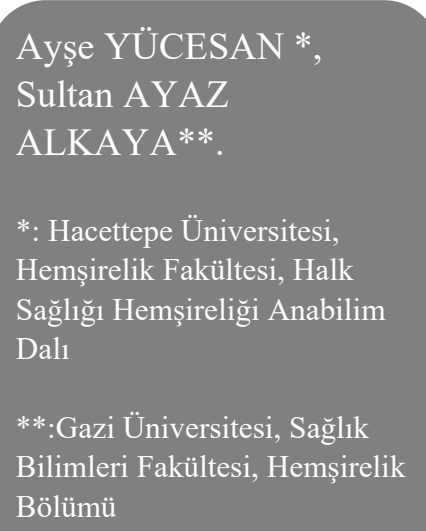

Yazışma Adresi:

Ayşe YÜCESAN

Hacettepe Üniversitesi, Hemşirelik

Fakültesi, Halk Sağlığı Hemşireliği

Anabilim Dalı

Hacettepe Üniversitesi Hemşirelik

Fakültesi Sıhhiye Kampüsü

Altındağ/Ankara

Telefon: 05303604133

Fax: 0 (312) 3127085

e-mail: amulayim@yahoo.com
$\ddot{O} \mathbf{z}$

Bireyin cinsel gelişimi konsepsiyon ile başlamakta ve yaşam boyunca devam etmektedir. Bu nedenle bireylere çocukluk çağından itibaren cinsel sağlık eğitimi verilmesi önem taşımaktadır. Cinsel sağlık eğitimi, çocukların ve gençlerin fiziksel, sosyal ve duygusal gelişiminin önemli bir bileşenidir. Kapsamlı bir cinsel sağlık eğitimi, bireyin yaşına uygun olarak, kültürel ve bilimsel olarak doğru bilgi edinmesine, kendi cinsel yaşamı ve ilişkileri hakkında bilinçli tercih yapmasına, tutum, inanç ve değerlerini oluşturmasına yardımcı olmaktadır. Gelişmiş ülkelerin pek çoğunda cinsel sağlık eğitimi okullarda verilmektedir. Ancak Türkiye'de ulusal eğitim programı içerisinde cinsel sağlık eğitimi ayrı bir ders olarak yer almamaktadır. Bu nedenle ülkemizde okul programlarına cinsel sağlık eğitimi ile ilgili ders ya da konuların eklenmesi ve uygulamaya geçirilmesi gerekmektedir. Cinsel sağlık eğitim programlarının oluşturulması ve yürütülmesinde okul sağlığı hemşirelerinin koordinatör, lider ve danışman rolü üstlenmesi önerilmektedir.

Anahtar Kelimeler: Cinsellik, cinsel sağlık, cinsel sağlık eğitimi, okul sağlığı hemşiresi.

\begin{abstract}
Human sexual development begins at conception and continues throughout life. For this reason, giving sexual health education from childhood to adulthood is important. Sexual health education is an important component of children's and youth's physical, social and emotional development. Comprehensive sexual health education offers age appropriate, culturally and scientifically accurate information, assists young people in developing a positive view of sexuality and makes informed choices about their sexual health. Moreover, it can help develop their own attitudes, beliefs, and values. Sexual health education should be appropriate to the age, developmental level and cultural and social backround of students. Sexual health education is given at schools in the most of the developed countries. However, sexual health education lesson is not in national curriculum
\end{abstract}


in Turkey. For this reason, sexual helath education lesson should be added to national curriculum. It is reccomended that school health nursing should assume coordinator, leadership and counseling role in developing and performing sexual health education programs.

reclassification.

Keywords: Sexuality, sexual health, sex education, sexual education, school nursing.

\section{Giriş}

Cinsellik biyolojik, psikolojik ve sosyal bileşenleri olan temel bir insan gereksinimi olup; cinsiyet, cinsel kimlik ve roller, cinsel yönelim, erotizm, üreme ve sosyal iyilik halini kapsayan bir kavramdır. Dünya Sağlık Örgütü (DSÖ) cinsel sağlığı "cinsellikle ilgili zorlama, ayrımcılık ve şiddetin olmadı̆̆ 1 , fiziksel, sosyal ve ruhsal olarak iyilik hali" olarak tanımlamaktadır (1). Cinsel sağlık eğitimi ile cinsel sağlık sorunlarını önlemek ve cinsel sağlığ1 geliștirmek için bireylere gerekli olan motivasyon, bilgi ve davranış becerileri kazandırmak ve kendi cinsel anlayışlarını geliştirmelerini sağlamak hedeflenmektedir. Bireyin cinsel gelișiminin döllenme ile başlaması ve yaşam boyu devam etmesi nedeniyle, çocukluk çağından itibaren cinsel sağlık eğitimi verilmesi önem taşımaktadir (2).

Gelişmiş ülkelerin çoğunda okullarda cinsel sağlık eğitimi yasal olarak zorunlu kılınmıştır. Ülkelere göre değişmekle birlikte; eğitimler okul sağlığı hemşireleri, doktorlar, öğretmenler, sosyal hizmet uzmanları ve psikologlar tarafindan yürütülmektedir (3-5). Ülkemizde ise bazı özel kurumlar ve Milli Eğitim Bakanlığ1 (MEB)'in iş birliği ile yürüttüğü projeler dışında ulusal eğitim müfredatında cinsel sağlık ile ilgili herhangi bir ders ya da uygulama bulunmamaktadır (6). Gelişmiş ve gelişmekte olan pek çok ülkede ilk cinsel deneyim yaşının düşmesi, cinsel yolla bulaşan hastalıklar $(\mathrm{CYBH})$, adölesan gebelikler ve kayıt dışı kürtaj sayısının artması okul müfredatına cinsel sağlık eğiti- mi ile ilgili ders ya da konuların eklenmesini zorunlu hale getirmiştir $(7,8)$. Ülkemizde de giderek artan cinsel sağlık sorunlarına rağmen Sağlık Bakanlığı (SB) ve MEB cinsel sağlık eğitiminin gerekliliğini göz ardı etmektedir. $\mathrm{Bu}$ makale okul çağı döneminde cinsel sağlık eğitiminin gerekliliğine ve okul sağlı̆̆ hemşirelerinin rollerine dikkat çekmek amacı ile yazılmıştır.

\section{Cinsel Sağlık ve Cinsel Sağlık Ĕgitimi}

Cinsel sağlık, ilk olarak 1994 yılında Kahire'de düzenlenen Uluslararası Nüfus ve Kalkınma Konferansı (ICPD)'nda “cinsel sağlık ve üreme sağlığı hakları" kapsamında ele alınmıştır. Bu konferansta çocuk ve gençlerin cinsel sağlık ve üreme sağlığ $\breve{l}_{1}$ ihtiyaçlarının yetişkinlerden fark11 olduğu vurgulanmıştır. 1995 yılında Pekin'de düzenlenen Dünya Kadın Konferansı'nda da gençlerin cinsel sağlık eğitimi almalarının önemi ve cinsel sağlık eğitiminin gerekliliği üzerinde durulmuştur (7-9).

Cinsel sağlık eğitimi yaşam boyu süren bilgi sahibi olma, değer, tutum ve inanç oluşturma sürecidir. Bu süreç gençlerin cinselliğe pozitif bakmalarına, kendi cinsel yaşamları hakkında bilinçli tercih yapmalarına, kendilerine özgü davranış ve değer oluşturmalarına yardımcı olmaktadır. Etkili ve uygun içerikli bir cinsel sağlik eğitim programı $\mathrm{CYBH}$, istenmeyen gebelikler ve cinsel istismarın önlenmesi gibi evrensel hedeflere ulaşmada önemli bir bileşendir (10-12). Literatürde gençlerin cinsel sağlık ile ilgili konularda yeterli bilgiye sahip olmadiğ açıkça görülmektedir. Stevens ve arkadaşları (2002) öğrencilerin fiziksel değişim, kimlik/ ilișkiler, cinsel sağlık, üreme sağllğ 1 ve cinsellik gibi konularda yeterince bilgili olmadıklar1n1 belirlemişlerdir (5). Ülkemizde 2007 yılında yapılan "Gençlerde Cinsel Sağlık ve Üreme Sağlığı Araştırması" raporunda gençlerin üreme organları, yapisı ve fizyolojisi, CYBH, HIV/ AIDS, CYBH'a bağlı ortaya çıkacak sağlık sorunları ve korunma yolları ile ilgili yeterli bilgilerinin olmadığ belirlenmiştir (13). Ayrıca, öğ- 
rencilerin mensturasyon, puberte, menstural hijyen, cinsel ilişki, CYBH, üreme gibi konularda da bilgi ihtiyacının olduğu göze çarpmaktadır (14-16). Cinsel sağlık ile ilgili bilgi eksikliğinin yanı sıra gençler cinsel sağlığı olumsuz etkileyebilecek davranış ve tutumlara da sahip olabilmektedir. Gençlerin doğum kontrol yöntemlerini kullanma oranı azalmakta, erken yaşta cinsel ilişki, CYBH,cinsel eş sayısı, istenmeyen gebelik ve yasal olmayan kürtaj sayısı artmaktadır (7, 8, 17-19). Gençlerde hem bilgi eksiğinin hem de cinsel sağlık ile ilgili yanlış tutum ve davranışların olması cinsel sağlık eğitim programlarını zorunlu hale getirmiştir. $\mathrm{Bu}-$ nun yanı sıra, cinsel sağlık eğitimi kapsamında gençlere yönelik karar verme, sorumluluk geliştirme ve iletişim becerilerinin kazandırılması gibi hedefler geliştirilerek ve multidisipliner bir yaklaşımla ele alınması ön görülmüştür $(10,12$, 20).

\section{Cinsel Sağlık Eğitim Programları}

Kapsamlı bir cinsel sağlık eğitim programı üreme sistemi, büyüme ve gelişme, aile yaşamı, mastürbasyon, gebelik, doğum, ebeveynlik, aile planlaması, düşük, cinsel istismar ve $\mathrm{CYBH}$ gibi konularda yeterli bilgi sağlamalıdır. Aileler, çocuklar ve gençleri cinselliğe ilişkin değerleri anlamaları, kendi değerlerini geliştirmeleri, kendi cinsel tutumlarını belirlemeleri ve öz güvenlerini artırmaları konusunda desteklemelidir. Ayrıca iletişim, karar verme, baskılara karşı koyma, olumlu ilişkiler oluşturma gibi kişiler arası becerilerini geliştirmelerine, kendi cinsel davranışlarıyla ilgili sorumluluk almalarına ve bunları yerine getirmelerine yardımcı olmalıdır (10). Küçük yaşlardan başlayarak verilen kapsamlı bir cinsel sağlık eğitimi çocuk ve gençlerde aşağıdaki özelliklerin gelişmesini sağlamaktadır $(17,21)$ :

-Fiziksel ve duygusal gelişimi anlama ve kabullenme,

-Bedeni hakkında olumlu duygular taşıma, bireysel farklılıkları kabullenme,

-Cinsel davranışlarıyla ilgili bilinçli ve mantıklı kararlar alma,

-Kadın ya da erkek olarak kendi cinsiyeti hakkında olumlu duygular taşıma,

-Cinsel konular hakkında rahat bir şekilde konuşma ve kendini ifade etme,

-Uygun ve uygun olmayan cinsel davranışları ayırt etme,

-Cinsel taciz ve istismara karşı kendini koruma, -CYBH ve istenmeyen gebeliklerden korunma.

Cinsel sağlık eğitiminin bireyin yaş, gelișim, toplumsal ve kültürel yapısına uygun olarak hazırlanması ve eğitim programının insan gelişimi, ilişkiler, bireysel beceriler, cinsel davranışlar, cinsel sağlık, toplum ve kültüre ilișkin konuları içermesi gerekmektedir. Ayrıca program riskli cinsel davranışları azaltmaya odaklanmalı ve cinsellikle ilgili sosyal baskıları da ele almalıdır (7, 21-23). Yapılan çalışmalarda uygulanan cinsel sağlık eğitimlerinin içeriği, amaçları, hedef grubu ve etkililiği farklılık göstermektedir. Amerika Bileşik Devletleri'nde sadece anne ve kızlarına yönelik geliştirilen cinsel sağlık eğitim programında anne-kız iletişiminin güçlendirilmesinin riskli cinsel davranışlardan kendini koruma, CYBH'a ilişkin bilgi düzeyi ve CYBH'1 önlemede etkinliği değerlendirilmiştir (24). Hindistan'da 15-20 yaş grubundaki erkek öğrencilere verilen ergenlik döneminde görülen değișiklikler, mastürbasyon, cinsel ilişki, CYBH ve korunma yolları, kontraseptif yöntemler ile ilgili akran eğitimine dayalı cinsel sağlık eğitim programının bilgi ve tutumlarda değişiklik sağladığı belirlenmiştir (25). Başka bir çalışmada ise 11-21 yaş aralığındaki öğrencilere cinsellikten kaçınma, kontrasepsiyon, fiziksel ve biyolojik büyüme ve gelişme konularını içeren cinsel sağlık eğitimi uygulanmış, eğitim sonunda gençlerde cinsel ilişki ve adölesan gebe sayısının azaldığ 1 , cinsellikle ilgili bilgi ve algıları artırdığı belirlenmiştir (27). Kirby ve arkadaşları gelişmiş ve gelişmekte olan ülkelerde yapılan çalışmaları incelemişler ve bu çalışmalarda cinsel sağlık eğitim programlarının daha çok cinsel ilişkiyi erteleme, 
cinsel eş sayısını azaltma, kontraseptif yöntem kullanımını artırma, CYBH'1 azaltma üzerine odaklandığını, güvenli cinsel davranışlarla ilgili bilgi ve tutum değişikliği sağladığını, risk alma davranışlarını azalttı̆̆ını, ancak adölesan gebelikleri önleme, HIV ve CYBH'1 azaltmada direkt olarak etkili olmadığını belirtilmişlerdir (26). Ülkemizde ise Öztürk ve Siyez'in çalışmasında ilköğretim 6. sınıf öğrencilerine yönelik hazırlanan cinsel sağlık eğitim programında, ergenlik dönemi özellikleri, üreme sağlığı, yakın ilişkiler, sağlıklı ve sağlıksız ilişkiler, karar verme ve hayır deme becerileri, ihmal ve istismar, toplumsal cinsiyet ve cinsellikle ilgili yanlıș inanıș gibi konulara yer verilmiștir. Bu eğitim programı sonunda öğrencilerin bilgi düzeyleri ve tutumlarında anlamlı değişiklikler olduğu bulunmuştur (22). Güler ve Yöndem çalışmasında 6. sınıf öğrencilerine yönelik verilen cinsel sağlık eğitiminin öğrencilerin ergenlik ve cinsel sağlik ile ilgili doğru bilgiler edinmelerinde etkili olduğu belirtmiştir (28).

\section{Cinsel Sağlık Eğitim Yöntemleri}

Okullarda cinsel sağlık eğitimi çeşitli yöntem ve uygulamalar aracılığ 1 ile verilmektedir (3, 19, 21, 23-25, 27-29).

-Cinsel sağlıkla ilgili konuların doğrudan ya da dolaylı olarak müfredatta yer alan biyoloji, psikoloji, sosyoloji, din dersi gibi derslerin içerisine entegre edilmesi ve farklı öğretmenler tarafindan aktarılması

-Cinsel sağlık eğitimi vermek amacıyla konusunda uzman kişilerin eğitimci olarak davet edilmesi

-HIV/AIDS önleme programı gibi programların içerisine cinsel sağlıkla ilgili farklı konuların eklenmesi

-Akran eğitimi modeli ile cinsel sağlıkla ilgili konuların akran öğrenciler tarafından anlatılmaS1

-Cinsel sağlık ile ilgili konularda uzman eğitimciler tarafindan aile eğitimi yapılarak ailenin çocuğunu eğitmesi sağlanabilir.

\section{Dünyada Cinsel Sağlık Eğitimi}

Dünyanın birçok ülkesinde, resmi olarak cinsel sağlık eğitim programları yürütülmektedir.

Finlandiya: Cinsel sağlık eğitimi ilk olarak 1970 yılında okul müfredatına girmiş, 1980’lere kadar devam etmiştir. Bu süre içerisinde adölesan gebeliklerde azalma sağlandığ için uygulaması şehirlere bırakılarak zorunlu hale getirilmiş, 2000 y1lında ise 13-15 yaş grubu için tamamen zorunlu olmuştur. Program içeriğinde 7. ve 8. sinıflar için cinsel sağlık ve üreme sağlığı ile ilgili biyoloji konularının yanı sıra menstruasyon, gebelik, doğum, ilk cinsel deneyim ve CYBH, 9. sınıflar için mastürbasyon, ejekulasyon, kürtaj, cinsel değer, duygular ve LGBT ile ilgili bilgiler yer almaktadır. Eğitimler çoğunlukla biyoloji ve sağlik eğitimi öğretmenleri tarafindan yürütülmektedir. Oyun, grup tartışmaları, sınav veya video gösterimi gibi farklı teknikler kullanılmaktadır (3).

Amerika Birleşik Devletleri: Cinsel sağlik eğitimi ülkenin eyaletlerinde ve bölgelerinde farklı şekillerde uygulanmaktadır. 22 eyalette okullarda hem cinsel sağlık eğitimi hem de CYBE/ HIV eğitimi verilirken, 15 eyalette yalnız CY$\mathrm{BE} / \mathrm{HIV}$ eğitimi verilmektedir. 13 eyalette ise cinsel sağlık eğitimi verilmemektedir. Pek çok okulda cinsel sağlık eğitimi 7. ve 9. sınıflarda yoğunlaşmaktadır. Ayrıca cinsel olarak aktif ergenlere cinsellikten kaçınma, toplumsal cinsiyet, cinsellik, istenmeyen gebeliklerin önlenmesi ve HIV'den korunma konularında bilgi ve beceriler ögretilmektedir $(5,21,30)$.

İngiltere: İlk olarak 1944 yılında cinsel sağlık eğitiminden söz edilmeye başlanmış, 1986 y1lında uygulanması șehirlerin yönetimine bırakılarak, tüm devlet okullarında velilerin isteğine bağlı olmak üzere 11 yaşından itibaren zorunlu hale getirilmiştir. Eğitim içeriğinde üreme, cinsellik ve cinsel sağlık, cinsel ilișkiden kaçınma konularına yer verilmektedir. Cinsel sağlık eğitiminden genel olarak okullardaki öğretmeler sorumludur. Ayrıca bazı eyaletlerde okul sağlı- 
ğ1 hemşireleri de bu eğitimlerde görev almaktadir $(3,4)$.

Danimarka: Cinsel sağlık eğitimi Danimarka'da 1900'lü yıllardan bu yana okul müfredatlarında yer almaktadır. Başlarda "hijyen" konuları altında anlatılan cinsel sağl1k, cinsel reform hareketlerinin başlamasından sonra 1970 yılında okullarda zorunlu bir ders olarak okutulmaya başlanmıștır. Genellikle 12-15 yaşlarda başlayan cinsel sağlık eğitimi zorunlu bir ders olarak müfredatta yer almasına karşın, öğretmenlerin ve okulların inisiyatifine bırakılmıștır. Cinsel sağlık eğitimi yaş gruplarına göre üc bölüme ayrılmış olup, 1-4. sınıflar için kadın-erkek arasındaki farklar, üreme, gebelik, doğum, aile planlaması, ailenin büyüklüğü ve ergenlik dönemi; 5-7. sınıflar için cinsel organlar, hormonlar, genetik, cinsel içgüdü, döllenme, doğum kontrolü, CYBH ve pornografi; 8-10. siniflar için bu konuların dıșında etik, ahlak, sosyal ve aile ile ilgili sorunlar ele alınmaktadır. Öğretmenlerin sorumluluğunda olan bu eğitimler okul sağlığı hemşireleriyle birlikte yürütülmektedir (8).

Fransa: Fransa'da 1920'lerde yürürlüğe giren bir yasa ile cinsellikle ilgili bilgiler yasaklanmıs ve bu yasa 1967'ye kadar uygulanmıștır. 1967 yılında dünyadaki AIDS tehlikesiyle birlikte, bu hastaliktan korunmanın bir yolu olarak kontrasepsiyon yöntemleri önem kazanmış ve cinsel sağlık eğitimine başlanmıştır. Bu dönemde daha çok kontrasepsiyon ve cinsellik hakkında genel bilgiler verilmiştir. 1973 yılında oluşturulan cinsel sağlık eğitim programı çerçevesinde öğrencilere üreme sistemi anatomisi ve fizyolojisi ile ilgili bilgi sağlama ve öğretmenlerin eğitimi hedeflenmiștir. 2001 y1lından itibaren bütün öğretim kademelerinde cinsel sağlık eğitimi zorunlu hale getirilmiştir. Eğitim içeriğinde cinselliğin fizyolojik, etik, duygusal, sosyal ve kültürel boyutları, riskli davranışların azaltılması ve önlenmesi, şiddet, cinsel istismar, homofobi ve irkçılığın önlenmesi gibi sosyal, bi- yolojik ve etik konular yer almaktadır. Bu eğitimler, öğretmenler, okul sağlığ1 hemşireleri, sosyal hizmet uzmanları ve diğer sağlık çalışanları tarafindan verilmektedir $(3,8)$.

\section{Türkiye'de Cinsel Sağlık Eğitimi}

Türk toplumunda cinsellik ve cinsellikle ilgili konulara ayıp, günah ve yasak olarak bakılmış ve bu nedenle aile içinde, toplumda veya okullarda bu konuya değinilmemiştir. Cinsel sağlık eğitiminin gerekliliği zaman zaman ele alınmış fakat çoğunlukla göz ard1 edilmiştir (31). Cinsel sağlık eğitimi ilk kez 1974 yılında, Türkiye Aile Planlaması Derneği'nin de katkısı ile gündeme getirilmiş, konuyla ilgili olarak bilgi ve tutumların araştırılması gerektiğine dikkat çekilmiștir. 1990'lı y1llarda tüm dünyada olduğu gibi Türkiye'de de HIV/AIDS yayılımıyla birlikte gençleri üreme sağlığı ve cinsel sağlık konularında bilgilendirmek ve buna yönelik sağlik hizmeti sunmak için, bazı gönüllü kuruluşların öncülüğünde Milli Eğitim Bakanlığg (MEB)'nın işbirliği ile özel projeler ve bölgesel eğitimler gerçekleștirilmiştir. Değişim Genç Kızlığa İlk Adım Projesi (1993-1999), Gençlerin Cinsel Sağlık Eğitiminin Desteklenmesi Projesi (19992003), Ergenlerin Sağlik Bilincinin Geliştirilmesi Projesi (2001-2003), Ergenlik Dönemi Değişimi Projesi (ERDEP) (1999-(...)) bu projelerden başlicalarıdır. Bunlar arasında en uzun süreli olan, ERDEP'tir. Bu proje kapsamında 81 ilde 6 . ve 7 . sinıf k1z ögrrenciler ve anneleri ile erkek öğrencilere yönelik bir günlük eğitimler düzenlenmiştir. Bu eğitimler ergenlik döneminde büyüme ve gelişme, üreme sisteminin anatomi ve fizyolojisi ve kişisel bakım başlıklar1 üzerinden gerçekleştirilmiştir $(6,21)$. Bu etkinlikler dışında okullarda ulusal eğitim progra$\mathrm{m}$ içerisinde cinsel sağlık eğitim ayrı bir ders olarak yer almamaktadır. Ancak 1996 yılından bu yana 9. sınıf müfredatında yer alan Sağlık Bilgisi Dersi kapsamında öğretmenler tarafından büyüme ve gelişme, ergenlik dönemi ve özellikleri, ergenlik döneminde olumlu tutum geliştirme, aile hayatı, aile planlaması, AIDS ve 
CYBH konuları öğrencilere anlatılmaktadır $(32,33)$.

\section{Cinsel Sağlık Eğitiminde Okul Sağlığı Hem- şiresinin Rolü}

Hemşireliğin özel alanlarından biri olan okul sağlığı hemşireliğinin sorumluluklarından biri de, okullarda çocukların sağlığını korumak ve geliștirmek amacıyla sağlık eğitimi uygulamaktır (34). Cinsel sağlık eğitimi kapsamında okul sağlığ hemşiresinin pek çok rol ve sorumluluğu bulunmaktadır. Okul sağlığı hemşiresi (3538);

-Açık iletişimi teşvik eden okul ortamı olușturmal1,

-Çocukluk döneminden itibaren tüm okul kademelerinde birbirini tamamlayıcı nitelikte devam eden cinsel sağlık eğitiminin planlanması, yürütülmesi ve değerlendirilmesinde eğitimcilerle birlikte görev almalı,

-Eğitim programı içeriğinin bilimsel olarak doğru, kanıta dayalı, kültür, yaş ve gelişim dönemine uygun olmasina katkıda bulunmalı,

-Aileler, öğretmenler, yöneticiler ve müfredat hazırlayanlarla iş birliği yaparak cinsel sağlık eğitiminin uygulanmasına tüm paydaşları dahil etmeli,

-Özellikle gebelik, CYBH ve tedavi yöntemleri, tecavüz ve tacizi önleme, hayır diyebilme becerisi geliştirme ve diğer cinsel sağlık konularına ilişkin bilgilerin yer aldığı bilgilendirme broşürleri oluşturmalı,

-Y1l boyunca güncellenen duyuru panoları hazırlamal1, materyallerin geliştirilmesine gençleri de dahil ederek onların daha etkin olmalarını sağlamalı,

-Özellikle cinsel gelişim, cinsel ilișkiyi erteleme, reddetme becerileri, CYBH ve doğum kontrol yöntemleri gibi cinsel sağllk eğitimi ile ilgili güncel konular üzerine yoğunlaşarak gençler için küçük grup tartışmaları düzenlemeli,

-Okullarda cinsel sağlık açısından riskli grupları belirlemeli, sağlı hizmetine ihtiyacı olanlara gereksinimleri doğrultusunda uygun çözüm yolları geliştirmeleri için rehberlik etmeli, -Cinsel sağlık konusunda kişilerin doğru bilgi kaynaklarına ulaşmaları için danışmanlık hizmeti vermeli,

-Cinsel sağlık ve üreme sağlığının geliştirilmesi için hazırlanan projelerde etkin olarak rol almalidır.

Bu bağlamda okul sağlığı hemşirelerinin aşağ1daki gibi örnek bir programı yürütmesi önerilebilir:

1-5 yaş arası çocuklar: Bu yaş grubu çocuklar için hazırlanan cinsel sağlık eğitim programları daha çok kreș, anaokulu ve ev gibi ortamlarda yürütülmektedir. Okul sağllğ 1 hemșiresi hem aileyi hem de çocuğu eğitim programına dahil etmelidir. Eğitim içeriğinde aile yapısı, aile hayatının önemi, aile/bakım verici ve çocuk arasındaki iletişimin geliştirilmesi, kültürel değerler, olumlu arkadaşlık ilişkileri geliştirme, cinsel organların isimleri, mahremiyet, iyi dokunuş/kötü dokunuş konularına değinilmesi bu yaş grubu çocuklar için uygun olabilmektedir. Ayrıca okul sağlığı hemșiresi çocukların olumlu arkadașlik ilişkileri geliștirmelerini teșvik etmeli, aile ve çocuğa yönelik rehberlik ve danışmanlık sağlamalıdır (39).

5-10 yaș çocuklar: Bu yaș grubundaki çocuklar için okul sağlığı hemşireleri, öğretmenler ve aileler ile iş birliği yapmalıdır. Eğitimlerin ev ve okulda devamlılığı sağlanmalıdır. Eğitimlerde cinsel ve üreme organlarının basit tanımları ve fonksiyonları, ergenlik döneminde görülebilecek kızlara ve erkeklere özgü fiziksel ve duygusal değişimler, beden imajı ve bireysel değişiklikler, cinsel istismar ve korunma yolları, olumlu arkadaşlık ilişkileri, aile hayatı ve mahremiyet gibi konulara değinilmelidir. Eğitimlerde ana amaç çocukların duygusal ve fiziksel sağlığını korumak ve geliștirmek olmalıdır. Öte yandan okul sağlığ hemşiresi özellikle istismar bulgularını gözlemlemeli, gerektiğinde raporlamalı, cocukları ve aileleri danıșmanlık alabilecekleri kurumlara yönlendirmelidir $(10,39)$. 
11-14 yaş çocuk ve gençler: Okul sağlığ hemşiresi ergenlik döneminde olan bu yaş grubundaki çocuk ve gençleri cinsel sağlık ve ilişkiler hakkında bilinçli karar vermeleri ve seçim yapmaları konusunda desteklemelidir. Eğitim içeriğinde ergenlik döneminde görülebilecek hormonal, fiziksel ve duygusal değişiklikler, olumlu ilişkiler geliştirme, cinsel ve romantik ilişkilere yönelim, doğurganlık, üreme sağlığı, doğum, hamilelik, CYBH ve korunma yolları, kontraseptif yöntemler, olumlu beden imajı geliştirme, cinsel taciz ve istismardan korunma, atılganlık becerileri geliştirme konularına yer verilmelidir $(10,39)$.

15-19 yaş gençler için: Okul sağlığı hemşiresi bu yaş grubundaki gençleri cinsel sağlık ve ilişkiler hakkında bilinçli karar vermeleri ve seçim yapmaları konusunda desteklemelidir. Cinsel yönden aktif olabileceklerinden kontraseptif yöntemler ve erișimi konusunda bilgilendirilmeleri gerekmektedir. Yetişkinlik öncesi dönem olduğu için yetişkinliğe hazırlık, otonomi geliştirme, cinsel ilişkiyi geciktirme, olumlu cinsel ve romantik ilișki geliștirme, olumlu beden imajı geliştirme, cinsel taciz ve istismardan korunma konularına eğitim içeriğinde yer verilmelidir (39).

Cinsel sağlık eğitimi Danimarka, İngiltere, Fransa, Yunanistan, Slovakya ve İzlanda gibi gelişmiş ülkelerde okul sağlıği hemşireleri tarafindan yürütülmektedir (3). 19 Nisan 2011 y1lında yürürlüğe giren hemşirelik yönetmeliğinde okul sağlığ 1 hemşiresinin cinsel sağlık eğitimi ile ilgili doğru sağlık bilgilerinin aktarılmas1 ve olumlu davranışların kazandırılmaS1 amacıyla sağlık eğitimi planlama ve yürütme görevi yer almaktadır (34). Ancak, ülkemizde okul sağlığı hemşirelerinin sayı olarak yetersiz olduğu bilinmektedir. Bu alanda çalıșan hemșirelerin daha çok özel okullarda çalıştığ 1 , okul sağlığı alanında uzman olmadığ1, ayrıca mevzuatta belirtilen görev ve sorumluluklarından daha çok kaza ve yaralanmalarda ilk yardım ve ilaç uygulaması yaptıkları belirtilmektedir (40).
Buna karşın, yapılan çalışmalarda öğrencilerin cinsel sağlık eğitimini uzman hemşireler gibi eğitimli sağlık personelinden almak istedikleri saptanmıştır $(19,41-44)$.

\section{Sonuç}

Türkiye'de özellikle son yıllarda yapılan çalışmalarda adölesanların cinsel sağlık eğitimi ihtiyacı olduğu açıkça ortaya konmuştur. Öte yandan dünya genelinde olduğu gibi Türkiye'de de giderek önemli bir sağlık sorunu olmaya başlayan $\mathrm{CYBH}$, adölesan gebelikler ve istemli düsüklerin önlenmesinde cinsel sağlık eğitimi önemli bir rol oynamaktadır. Cinsel sağlık eğitimin verileceği yas grubu ve eğitim içeriği ülkenin gelişmişlik düzeyi, sosyoekonomik koşulları, sağlık sistemi ve kültürel yapısına göre farklılık göstermekle birlikte cinsel sağlıkla ilgili bilgiyi artırdığı, güvenli cinsel davranışlarla ilgili tutum değişikliği sağladığı açıkça görülmektedir. Türkiye'de yürütülen projelerin kısa süreli olması, tüm adölesanlara ulaşılamaması ve daha çok bilgi kazandırmaya yönelik olması nedeniyle gereksinimleri karşılamada yeterli olmadığı düşünülmektedir. Ayrıca Sağlık Bilgisi Dersi kapsamında anlatılan cinsel sağlığa ilişkin konuların önerilen cinsel sağlık eğitim programlarının içeriğini kapsamadığı açıkça görülmektedir. Bu nedenle ülkemizde çocukluk çağından itibaren tüm eğitim/öğretim kademelerine kapsamlı cinsel sağlık dersi ya da konularının eklenmesi ve uygulamaya geçirilmesi gerekmektedir. Gelişmiş ülke örneklerine, ilgili yasal mevzuata ve okul sağlı̆̆ hemşirelerinin rollerine bakıldığında cinsel sağlık eğitiminde uzman okul sağlığı hemşirelerinin görev almasının eğitimlerin etkinliğini artırabileceği düşünülmektedir. Ayrıca, bu alanda görev yapacak okul sağlığı hemşirelerinin lisans eğitimi sonras1 halk sağlığ 1 hemşireliği alanında lisansüstü eğitim alması ve bunun yasalarla desteklenmesi önerilmektedir. 


\section{Kaynaklar:}

1.Dünya Sağlık Örgütü. (1975). Education and treatment in human sexuality: the training of health professionals. http://apps.who.int/iris/ bitstream/10665/38247/1/

WHO_TRS_572_eng.pdf Erişim Tarihi: $22.12 . \overline{2} 015$

2.Sex Information and Education Council of Canada. (2005). Sexual health education in the schools: Questions \& Answers. Canada. http:// www.sieccan.org/pdf/she q\&a 3rd.pdf Erişim Tarihi: 24.12.2015

3.European Parliament. (2013). Policies for sexuality education in the European Union. http://www.europarl.europa.eu/RegData/etudes/ note/join/2013/462515/IPOL-FEMM_NT

(2013)462515_EN.pdf Erişim Tarihi: 22.12 .2015

4.GOV.UK. (2015). The National Curriculum. https://www.gov.uk/national-curriculum/othercompulsory-subjects Erişim Tarihi: 11.01.2016 5.Stevens S, Thompson EM, Vinson J, Greene A, Powell C, Licona AC, Russell S. Informing sexuality education through youth-generated anonymous questions. Sex Education 2012; 13 (1): 84-98.

6.İnsan Kaynağı Geliștirme Vakfi. Öğretmen ve öğretmen adayları için cinsel sağlık eğitimi. İstanbul: Renk Matbaası: 2006.

7.Talib J, Mamat M, Ibrahim M, Mohamad Z. Analysis on sex education in schools across Malaysia Procedia - Social and Behavioral Sciences 2012; 59: 340-8.

8.The International Planned Parenthood Federation. (2006). Sexuality education in Europe. http://www.ippfen.org/en/Resources/

Publications/

Sexuality+Education+in+Europe.htm Erișim Tarihi: 28.12.2015

9.United Nations Populations. (2007) Framework for Action on adolescents and youth: opening doors with young people: 4 Keys. http://www.unfpa.org/sites/default/files/pubpdf/framework youth.pdf Erişim Tarihi: 08.01 .2016
10.Sexuality Information and Education Council of The United States. Guidelines for comprehensive sexuality education, 3rd ed. New York: Fulton Press; 2004.

11.Bernard LW, Immroth BF. Health information for youth: The public library and school library mediacenter role. USA: Libraries Unlimited; 2007.

12.United Nations Educational, Scientific and Cultural Organization. International technical guidance on sexuality education. Paris: UNESCO Press; 2010.

13.Nüfus Bilim Derneği ve Birleşmiş Milletler Nüfus Fonu. (2007). Türkiye Gençlerde Cinsel Sağlık ve Üreme Sağlığı Araştırması. http:// www.nd.org.tr/custom/odesismc/

Turkce_rapor.pdf Erişim Tarihi: 11.01.2016

14.Gölb̄aşı Z, Doğaner G, Erbaş N. 6-8. Sınıf adölesan kızlara akran eğitimi yöntemiyle uygulanan menstruasyon sağlı̆̆ eğitiminin bilgi ve davranışlar üzerindeki etkisi. TAF Preventive Medicine Bullettin 2012; 11(2): 191-98.

15.Sommart J, Sota C. The effectiveness of a school-based sexual health education program for junior high school students in Khon Kaen, Thailand. Procedia-Social and Behavioral Sciences 2013; 91: 208-14.

16.Jarrah SS, Kamel SA. Attitudes and practices of school-aged girls towards menstruation. International Journal of Nursing Practice 2012; 18: 308-15.

17.Abel G, Fitzgerald L. When you come to it you feel like a dork asking a guy to put a condom on': is sex education addressing young people's understandings of risk? Sex Education 2006; 6(2): 105-19.

18.Zhang L, Chow E, Wilson EP. Distributions and trends in sexual behaviors and HIV incidence among men who have sex with men in China. BMC Public Health [online]. 2012; 12: 546-556. http://

bmcpublichealth.biomedcentral.com/ articles/10.1186/1471-2458-12-546. Erisim Tarihi: 11.01 .2016

19.Dağ H, Dönmez S, Şirin A, Kavlak O. Ak- 
ran eğitiminin üniversite öğrencilerinin cinsel sağlık, konusundaki bilgi düzeylerine etkisi. Anadolu Hemşirelik ve Sağlık Bilimleri Dergisi 2012; 15(1): 10-7.

20.Brunk T, Morris S, Rye BJ, Meaney GJ, Yessis J, Wenger L, McKays A. Girl time: Development and implementation of a healthy sexuality program for girls in Grades 7 and 8 . The Canadian Journal of Human Sexuality 2008; 17(1-2): 71-82.

21.Cinsel Eğitim Tedavi ve Araştırma Derneği. (2007). Gençlik ve Cinsellik. http:// www.cetad.org.tr/CetadData/

Book/32/269201116835-

bilgilendirme_dosyasi_7.pdf Erişim Tarihi: 11.01.2016

22.Öztürk B, Siyez DM. İlköğretim 6. sinıf öğrencilerine yönelik cinsel eğitim programının etkililiğinin incelenmesi. Ege Eğitim Dergisi 2015; 1(16): 30-55.

23.Lederman RP, Chan W, Roberts-Gray C. Parent-adolescent relationship education (PARE): Program delivery to reduce risks for adolescent pregnancy and STDs. Journal of Behavioral Medicine 2010; 33(4): 137-43.

24.Romo LF, Bravo M, Tschann JM. The effectiveness of a joint mother-daughter sexual health program for Latina early adolescents. Journal of Applied Developmental Psychology 2014; 35(1): 1-9.

25.Kalkute JR, Chitnis UB, Mamulwar MS, Bhawalkar JS, Dhone AB, Pandage AC. A study to assess the knowledge about sexual health among male students of junior colleges of an urban area. Medical Journal of Dr. D.Y. Patil University 2015; 8(5): 5-11.

26.Kirby DB, Laris BA, Rolleri LA. Sex and HIV education programs: Their impact on sexual behaviors of young people throughout the World. Journal of Adolescent Health 2007; 40: 206-17.

27.Gosser JJ, Wimer CD, Lloyd CA. A new sexual education program: Evaluation of effectiveness. American Journal of Social Sciences, Arts and Literature 2014; 1(1): 1-13.
28.Güler S, Yöndem ZD. Ergenlik ve Cinsel sağlık eğitimi ile ilgili grup rehberliğinin 6 . s1nıf öğrencilerinin bilgi ve tutumlarına etkisi. İlköğretim Online [Online]. 2007; 6(1): 2-10. http://dergipark.ulakbim.gov.tr/ilkonline/ article/viewFile/5000038321/5000037177 Erişim Tarihi: 11.01.2016

29.Jaworsky D, Larkin J, Sriranganathan G, Clout L, Janssen J, Campbell L, et al. Evaluating youth sexual health peer education programs: Challenges and suggestions for effective evaluation practices. Journal of Education and Training Studies 2013; 1(1): 227-34.

30.Planned Parenthood Federation of America. (2012). https://www.plannedparenthood.org/ files/3713/9611/7930/Sex_Ed_in_the_US.pdf

Erişim Tarihi: 11.01.2016

31.Babacan SS. İnsan seksüalitesinin kültürel ve psikososyal yönleri. Kastamonu Eğitim Dergisi 2003; 11(1): 131-6.

32.Milli Eğitim Bakanlığı. (2010). Sağlık Bilgisi Dersi (9. Sınıf) Öğretim Program1. http://ttkb.meb.gov.tr/program2.aspx? islem $=1 \& \mathrm{kno}=91$ Erişim Tarihi: 11.01.2016 33.Milli Eğitim Bakanlığ1 (MEB). (2015). 2015 -2016 Eğitim Öğretim Yılında Okutulacak İlk ve Orta Öğretim Ders Kitapları. http:// www.meb.gov.tr/2015-2016-egitim-ogretimyilinda-okutulacak-ilk-ve-orta-ogretim-derskitaplari/duyuru/9544 Erişim Tarihi: 11.01.2016

34.Resmi Gazete. (2011). Hemşirelik yönetmeliğinde değişiklik yapılmasına dair yönetmelik. http://www.resmigazete.gov.tr/

eskiler/2011/04/20110419-5.htm Erişim Tarihi: 11.01.2016

35.Tietjen-Smith T, Balkin R, Kimbrough S. Development and validation of the sex education confidence scale (SECS). Journal of Education and Human Development 2008; 2(2): 1 6.

36.Chang YT, Hayter M, Lin ML. Pubescentmale students' attitudes towards menstruation in Taiwan: Implications for reproductive health education and school nursing practice. Journal 
of Clinical Nursing 2011; 21: 513-21.

37.Jackson V. What is the role of the school nurse in sexual health education. NASN School Nurse 2011; 26(3): 146-7.

38.National Association of School Nurses. (2012). School Health Education about Human Sexuality. https://www.nasn.org/ PolicyAdvocacy/PositionPapersandReports/

NASNPositionStatementsFullView/tabid/462/ ArticleId/43/School-Health-Education-aboutHuman-Sexuality-Revised-2012 Erişim Tarihi: 11.01.2016 39.GOV.UK (2014). Health Visiting and School Nurse Programme: Supporting implementation of the new service offer: Developing strong relationships and supporting positive sexual health. https://www.gov.uk/government/ uploads/system/uploads/attachment_data/ file/299269/

Sexual_Health_Pathway_Interactive_FINAL.p df Erişim Tarihi: 10.10.2016

40.Bulduk S, Pek H. İstanbul'da özel ilköğretim okullarında çalışan hemşirelerin rol ve işlevlerinin incelenmesi. Cumhuriyet Üniversitesi Hemşirelik Yüksek Okulu Dergisi 2005; 9(2): 40-8.

41.Metin Z, Üniversite son sinıf öğrencilerinin cinsel sağlık ve üreme sağlığı bilgi düzeyleri. İstanbul: Okan Üniversitesi Sağlık Bilimleri Enstitüsü; 2015.

42.Geçici F, Gaziantep üniversitesi öğrencilerinin cinsellik ve üreme sağlığı hakkındaki bilgi düzeylerinin incelenmesi. Gaziantep: Gaziantep Üniversitesi Sağlık Bilimleri Enstitüsü; 2011. 43.Pınar G, Doğan N, Ökdem Ş, Algıer L, Öksüz E. Özel bir üniversitede okuyan öğrencilerin cinsel sağl1kla ilgili bilgi tutum ve davranışları. Tıp Araştırmaları Dergisi 2009; 7(2): 10513.

44.Kaya F, Serin Ö, Genç A. Eğitim fakültesi birinci sınıf öğrencilerinin cinsel yaşamlarına ilişkin yaklaşımlarının belirlenmesi. TSK Koruyucu Hekimlik Bülteni 2007; 6(6): 441-8. 